\title{
Diversity, Recordkeeping, and Archivy
}

\author{
Guest Editors: \\ Rebecka Taves Sheffield, Archives of Ontario, Canada \\ Janet Ceja, Simmons University, USA \\ Stanley H. Griffin, The University of the West Indies, Jamaica
}

Keywords: anti-racism; archives; archival studies; Black histories; de-colonization; genealogy; indigenizing; recordkeeping

Publication type: editorial

\section{Editorial}

$\mathrm{T}$

his special issue of IJIDI on "Diversity, Recordkeeping, and Archivy" brings together research from archival scholars, practitioners, and educators working to challenge the persistence of whiteness, classism, sexism, heterosexism, transphobia, and colonizing approaches in archives.

As a profession, the field of archives began with a particular Western Imperialist axiology that continues to inform what many archivists value today. These values underpin our methods and practices by presupposing what ought to be in an archive, how we ought to behave as archivists, who is able to access collections, and how we ought to serve those who access our collections. By extension, archival studies has emerged as an academic discipline with a set of tacit assumptions about records and recordkeeping practices that neatly align with this axiology.

At present, however, the discipline of archives-sometimes referred to in North America as "archivy"-is experiencing a transformative moment. In part, this seismic shift in our understanding of what archives are, what they do, and who they serve, is part of a larger postmodern moment that has afforded us new tools to critically examine the assumptions that structure our work. This new era is also fueled by, what archival activist Ariel Schudson has called, a "strong feeling of discontent and aggravation" about a "willful and continued lack of representation" of BIPOC (Black, Indigenous and people of colour) in archivy (Schudson, interviewed in On-Call Research Team \#1, 2016). One might suggest that those of us working in the global North are witnessing a diversity turn in archives. We are increasingly concerned about representation, both in the profession and in the collections we cultivate, and about building a more inclusive discipline overall. We, the guest editors of this special issue, present a collection of articles that not only contribute to this diversity turn, but also go one step further to challenge the very limitations of 'diversity' as an organizing principle in archivy.

This issue opens with the research article, "Brick Walls and Tick Boxes: Experiences of Marginalised Workers in the U.K. Archive Workforce" by Kirsty Fife and Hannah Henthorn. In this paper, the authors report on the results of their recent survey of U.K.-based information professionals to expose the many barriers that various cultural groups and/or working-class people experience when navigating typical pathways to entering the archives profession. Fife

The International Journal of Information, Diversity, \& Inclusion, 5(1), 2021

ISSN 2574-3430, https://jps.library.utoronto.ca/index.php/ijidi

DOI: $10.33137 /$ ijidi.v5i1.36003 
and Henthorn take a decidedly personal approach to exploring the issues of workforce precarity, whiteness, and classism in the profession and how these conditions disproportionately impact marginalised workers. The authors centre the voices of their participants to highlight lived experiences and to give further evidence to support the feelings of "discontent and aggravation" Schudson has described.

Whereas as Fife and Henthorn's work exposes the significant personal toll required to enter, qualify, and progress within the profession, the next article in this issue reports on the ways in which the U.K. profession has responded to diversity issues. In "Against Whitewashing: The Recent History of Anti-Racist Action in the British Archives Sector," Alicia Chilcott, Kirsty Fife, James Lowry, Jenny Moran, Arike Oke, Anna Sexton, and Jass Thethi describe the problem of white supremacy in U.K. archives and provide an overview of how some professional organizations are responding. The authors focus on a particular flashpoint of the 2019 annual meeting of the Archives and Records Association (ARA), during which archivists from a variety of backgrounds came together to develop a strategic and coordinated approach to define and realize a vision of a more inclusive profession.

What does an inclusive profession look like? What does diversity mean for archives and archivists? As editors of this volume, we struggle with the concepts of diversity and inclusion. The term diversity works across a variety of contexts because, like the term "race", "diversity" floats around like an empty signifier -it absorbs meanings and can be framed as benign or controversial, depending on the intent of the user or the orientations of the receiver (Haine, et al., 2019). Because of this linguistic vagueness, diversity can actually maintain normative order and oppressive power relations by obscuring the precision we need to actually talk about systemic imbalances of power. In fact, as we discovered reading and editing the articles for this issue, diversity is often used as code for non-white, polycultural, and sociolinguistically complex or for the process of othering whiteness. Diversity is also framed politically by being compared against the more radical aims of liberation, a term with a long history in social movements across the world. The conceptual limitations of diversity are also visible in the library and information science field (LIS), where some but certainly not all of the discussion about archives takes place. As David James Hudson (2017) notes, the LIS diversity paradigm "treats racism largely as a problem of monocultural homogeneity, identifying multicultural heterogeneity as its vision of racial justice and inclusion as its central anti-racist framework" (p. 6). He cautions that, "to be included in a space is not necessarily to have agency within that space" (p. 13). Tania Canas (2017), who in part inspired this issue, goes so far as to claim that "diversity is a white word" (para. 2). As such, the term "diversity" is employed to diffuse tensions, not to confront them or move through them.

In "A Weapon and a Tool: Decolonizing Description and Embracing Redescription as Liberatory Archival Praxis," Tonia Sutherland and Alyssa Purcell intentionally discuss the limitations of diversity as a concept. They remind us that "diversity initiatives are only meaningful to the extent that unjust systems are maintained and enforced, which ultimately evades and neglects issues of oppression and dehumanization." The article offers perspective on how diversity and inclusion efforts in archives must go beyond making collections about marginalized groups openly accessible; they must also account for the oppressive systemic practices that exist within our field. The authors focus on two cases: the redescription of the Hawai' $i$ State Archives' M-93 Queen Lili'uokalani Manuscript Collection finding aid and the digitization of the archives of Atlantic slavery. For the latter, Sutherland and Purcell point out that, while digitization promises greater access to historical knowledge, these types of projects can fall prey to the problem of

The International Journal of Information, Diversity, \& Inclusion, 5(1), 2021

ISSN 2574-3430, jps.library.utoronto.ca/index.php/ijidi/index

DOI: $10.33137 /$ ijidi.v5i1.36003 
reinscribing racist ideologies by "uncritically circulat[ing] records rooted in generational trauma, hatred, and genocide." Through these cases, Sutherland and Purcell discuss how descriptive language can reveal messy-racist-histories and show how a critical descriptive practice can be used as a liberatory praxis designed to confront racist and colonial archival systems.

Another way to overcome the limitations of diversity as an organizing principle is to reject the rosy outcomes that this paradigm promises and embrace the axiom of progress, not perfection. We can do better or, as Chilcott et. al. implore of us, we can "be braver". Developing the courage to critically examine our practices and methods is a core message in "Ancestry.com's Race Stories: Examining Whiteness on the Genealogy Web" by Anna Robinson-Sweet. In this article, Robinson-Sweet examines the practice of genealogy in the era of digital access and commercial DNA testing to reveal the connections between family history and the privileging of whiteness. In doing so, she deftly unmasks Ancestry's "willful ignorance" in architecting a site that "effectively erases the violence at the root of many family trees by failing to give users the ability to explain or acknowledge ancestors born of rape, particularly ancestors born to enslaved women and their enslavers." Robinson-Sweet implicates archival actions and partnerships that have allowed genealogical websites to obscure relationships that brutally connect Black families to white families. Robinson-Sweet then offers concrete steps for archivists to challenge the digital architectures that reinscribe this violence into digital architectures and practices.

Identifying and understanding the ways in which archival methods and practices can harm, oftentimes unintentionally, is a critical first step. The final article in this issue describes how institutional archives can potentially retraumatize Indigenous visitors and researchers, many of whom access these repositories in search of records that document first order violence. In "Laughter Filled the Space: Challenging Euro-Centric Archival Spaces," Krista McCracken and Skylee-Storm Hogan describe the ways in which archives are designed in ways that are spatially oppressive and fail to support the mental health of those engaged in researching records of trauma. They compare the strangeness of these spaces to those designed by and for Indigenous communities. In particular, they describe how the Shingwauk Residential Schools Centre (SRSC) has been designed around Indigenous practices, such as making available tobacco tie offerings and modular furniture to allow for family and group conversation. McCracken and Hogan reimagine archival spaces that are responsive to the emotional and physical needs of Indigenous visitors, and where archivists are knowledgeable about Indigenous cultures and their practices are trauma-informed. While McCracken and Hogan acknowledge that public archives cannot be decolonized-they are structures of colonizing agents-archivists can participate in decolonizing work that forms part of a larger movement to support Indigenous rights and self-determination. Linda Tuhiwai Smith's (2013) twenty-five Indigenous projects are befitting of the work done here as these authors demonstrate what it means to represent, envision, reframe, revitalize, name, and create as a part of this larger Indigenous movement.

We end this editorial with a glimpse into our own journey to bring these articles together. Throughout our editorial meetings, we discussed how the concepts of diversity and inclusion are socialized differently within each of the regions that we reside. In the U.S., the term 'diversity' came into usage in the late 1970s, when it was used to uphold the value of affirmative action programs, which focus on access to education and employment by granting special consideration to historically excluded groups, specifically racial minorities and women (Regents of the University of California v. Bakke 2020). In Canada, the idea of "cultural diversity" emerged alongside the multicultural policy, adopted by the federal government in the 1970s and 1980s (Jedwab, 2020). Designed as a response to rising francophone nationalism and increasing

The International Journal of Information, Diversity, \& Inclusion, 5(1), 2021

ISSN 2574-3430, jps.library.utoronto.ca/index.php/ijidi/index

DOI: $10.33137 /$ ijidi.v5i1.36003 
immigration, the first iteration of the policy acknowledged Canada as a nation settled by a plurality of cultural groups, each with intrinsic value. Over time, diversity has taken on an increasingly larger scope so that the term now refers to LGBTQ2+ (lesbian, gay, bisexual, trans, queer, and two-spirit) individuals and disabled people, in addition to differences in race, religion, ethnicity and country of origin. In the Caribbean, diversity is typically described and celebrated as key social and political signifiers of triumph over the horrors of racially-stratified plantation societies. Jamaica, like Canada, is a member of the Commonwealth of Nations and a former territory of the British Empire. In both countries, diversity, therefore, is also bound together with discussions of colonialism and Indigeneity. Distinct histories, however, have resulted in different understandings of how class, race, gender, and sexuality intersect to produce and uphold systems of power.

Still, recognizing diversity is not the same as ensuring inclusion, nor is inclusion necessarily liberatory. We are therefore careful not to misrepresent this issue as comprehensive or universal, nor do we want to undervalue the fight for equity and representation elsewhere or in contexts that we do not fully understand or embody. What we do want to accomplish with this special issue is to spark conversation and to acknowledge the breadth of research and scholarship on diversity, recordkeeping, and archivy. The five articles here are stellar examples of that work.

\section{References}

Canas, T. (2017). Diversity is a white word. ArtsHub Australia. https://www.artshub.com.au/education/news-article/opinions-andanalysis/professional-development/tania-canas/diversity-is-a-white-word-252910

Haine, R., Hall, S., Jhally, S., Quarzo-Cerina, A. (2019). Race: The floating signifier. Media Education Foundation. https://www.mediaed.org/transcripts/Stuart-Hall-Race-theFloating-Signifier-Transcript.pdf

Hudson, D.J. (2017). On "diversity" as anti-racism in library and information studies: A critique. Journal of Critical Library and Information Studies 1(1), 1-36. https://doi.org/10.24242/jclis.v1i1.6

Jedwab, J. (2020, March 20). Multiculturalism. The Canadian encyclopedia. Historica Canada. Retrieved January 19, 2021. https://www.thecanadianencyclopedia.ca/en/article/multiculturalism

On-Call Research Team \#1. (2016) \#ArchivesSoWhite in the words of Ariel Schudson. Society of American Archivists' Issues and Advocacy Section blog. https: / / issuesandadvocacy.wordpress.com/tag/archives_so_white/

Regents of the University of California v. Bakke. (2012). Columbia electronic encyclopedia, $\left(6^{\text {th }}\right.$ ed.). https://www.infoplease.com/encyclopedia/social-science/law/cases/universityof-california-vbakke

Smith, L.T. (2013). Decolonizing methodologies: Research and Indigenous peoples. Zed Books Ltd.

The International Journal of Information, Diversity, \& Inclusion, 5(1), 2021

ISSN 2574-3430, jps.library.utoronto.ca/index.php/ijidi/index

DOI: $10.33137 /$ ijidi.v5i1.36003 
Rebecka Taves Sheffield is an information professional and senior policy advisor for the Ontario Public Service. She holds a PhD in Information Studies from the University of Toronto (UofT) iSchool and is a graduate of the Mark S. Bonham Centre for Sexual Diversity Studies. She also holds a MIST with a specialization in archives and records management (UofT) and a BA in women's and gender studies (University of Saskatchewan). Rebecka's research interests include digital recordkeeping, archival studies, cultural heritage, and LGBTQ2+ histories. Her work has been published in Archivaria, American Archivist, Radical History Review, Library Trends, and Papers/Cahiers. Rebecka's recent book, Documenting Rebellions (Litwin, 2020), explores the emergence, development and sustainability strategies of four lesbian and gay community archives in queer times.

Janet Ceja holds a PhD in Library and Information Science with a specialization in Archives from the University of Pittsburgh. She has worked as an audiovisual archivist and assistant professor at Simmons University and the University of Arizona. Her research focuses on the social and community aspects of preserving cultural heritage materials, as well as the information practices of Latinx communities in the United States. She has been published in The Moving Image, Library Quarterly, and American Archivist.

Stanley H. Griffin holds a BA (Hons.) in History, and a PhD in Cultural Studies (with High Commendation), from the Cave Hill Barbados Campus of The University of the West Indies, and an MSc in Archives and Records Management (Int'l), University of Dundee, Scotland. Formerly the Archivist-in-Charge of the UWI Archives, he is Lecturer in Archival Studies and coordinates the Graduate Programme in Archives and Records Management in the Department of Library and Information Studies, UWI Mona Campus, Jamaica. Stanley's research interests include Multiculturalism in Antigua and the Eastern Caribbean, the Cultural Dynamics of intra-Caribbean migrations, Archives in the constructs of Caribbean culture, and community archives in the Caribbean. His most recent publications include Decolonizing the Caribbean Record: An Archives Reader (Litwin, 2018), a co-edited work with Jeannette Bastian and John Aarons.

The International Journal of Information, Diversity, \& Inclusion, 5(1), 2021

ISSN 2574-3430, jps.library.utoronto.ca/index.php/ijidi/index

DOI: $10.33137 /$ ijidi.v5i1.36003 